\title{
HUBUNGAN ANTARA PERSEPSI GURU TENTANG KONDISI FISIK LINGKUNGAN KERJA DENGAN MOTIVASI PRESTASI GURU SMK ABDI NEGARA BINJAI TAHUN PEMBELAJARAN 2018/2019
}

\author{
Hartini, Nurul Hasanah, Muhlis Fahdiar Sembiring \\ STKIP Budidaya Binjai
}

\begin{abstract}
ABSTRAK
Penelitian ini dilaksanakan di SMK Abdi Negara Binjai pada tahun 2018. Sampel penelitian ini berjumlah 31 orang guru. Teknik pengambilan sampel menggunakan random sampling. Metode yang digunakan dalam penelitian ini merupakan jenis penelitian kuantitatif dengan alat ukur berupa skala lingkungan kerja dan skala motivasi berprestasi. Teknik analisis data yang digunakan dalam penelitian ini adalah korelasi product moment dari pearson dengan menggunakan SPSS (Statitical Package For The Social Sciene) 20.0 For Windows Program. Berdasarkan hasil analisis data diperoleh nilai korelasinya atau $\mathrm{p}=0,000$ yang $\mathrm{p}<0,05$ maka yang artinya ada hubungan yang signifikan antara lingkungan kerja dengan motivasi prestasi. Nilai variabel motivasi prestasi terdistribusi secara normal dengan nilai $\mathrm{p}>0,05(0,967>0,05)$. Dan nilai variabel lingkungan kerja terlihat secara normal dengan nilai $\mathrm{p}>0,05(0,978>0,05)$. Nilai linearitas sebesar 1,000 atau $\mathrm{p}>0,05$ yang artinya kedua variabel berhubungan secara signifikan. Hasil reliabilitas menggunakan formula koefisien Crobach'Alpha di nyatakan tinggi jika mendekati angka 1, skala lingkungan kerja 0,940 dan skala motivasi prestasi 0,931 dan dua skala tersebut dapat dilihat bahwa reliabilitas skala sangat kuat karena nilai reliabilitas mendekati angka 1. Analisis ini dengan mengkorelasikan masing-masing skor item dengan skor total. Dan hasil validasi skala lingkungan kerja dari 40 skala yang di uji terdapat 6 item yang tidak valid artinya $p<0,025$, sedangkan skala motivasi prestasi dari 40 item yang di uji terdapat 5 item yang tidak valid.
\end{abstract}

Kata Kunci : lingkungan kerja, motivasi prestasi

\section{PENDAHULUAN}

Guru merupakan jabatan profesi yang memerlukan keahlian khusus sebagai pendidik professional dilingkungan sekolah Undang-undang nomor 14 Tahun 2005 tentang Guru dan Dosen Pasal 1 ayat 1 menyebutkan bahwa guru adalah pendidik professional dengan tugas utama mendidik, mengajar, membimbing, mengarahkan, melatih, menilai dan mengevaluasi peserta didik pada pendidikan anak usia dini melalui jalur formal pendidikan dasar dan pendidikan menengah. Guru memiliki peranan yang sangat penting dalam meningkatkan mutu pendidikan salah satu cara dalam rangka meningkatkan mutu pembelajaran adalah dengan meningkatkan kemampuan guru dalam mengembangkan dan mendesain pembelajaran sebagai upaya meningkatkan kompetensi guru, khususnya kompetensi professional. Guru sebagai seorang pendidik harus memiliki kinerja yang baik dalam pembelajaran mulai dari perencanaan pembelajaran sampai 
mengevaluasi pembelajaran. Kinerja yang baik tersebut tentu akan berpengaruh besar terhadap siswa dan kemajuan pendidikan nantinya.

Fenomena kinerja guru saat ini pada kenyataannya guru tidak dengan mudah menjalankan tugasnya dan mengembangkan potensi dirinya karena dihadapkan berbagai masalah dalam kehidupannya serta kurangnya fasilitas yang diberikan dalam mengajar sehingga dalam menjalankan tugasnya sebagai seorang pendidik dalam memberikan materi pembelajaran kepada peserta didik tidak disertai dengan persiapan-persiapan secara matang, apalagi menambah wawasan dan pengetahuan dari sumber-sumber lain sehingga akan memunculkan kinerja para pendidik yang kurang produktif. Ahmad rohani mengemukakan bahwa mengajar bukanlah tugas sederhana, aktifitas mengajar adalah sangat urgen sebab berkaitan dengan upaya mengubah, mengembangkan, dan mendewasakan insane didik. Oleh karena itu guru dalam mengajar dituntut untuk bekerja secara professional dan disiplin dalam menjalankan tugasnya.

Setiap profesi membutuhkan motivasi, salah satunya adalah motivasi berprestasi. Karena motivasi berprestasi mempengaruhi kinerja professional guru. Sebab jika motivasi berprestasi tinggi maka kinerja professional guru akan tinggi. Begitu pula sebaliknya, jika motivasi berprestasi rendah maka kinerja profesional guru akan rendah. Motivasi Berprestasi merupakan suatu dorongan dengan ciri-ciri seseorang melakukan pekerjaan dengan baik dan kinerja yang tinggi. Kebutuhan berprestasi tinggi merupakan suatu dorongan yang timbul pada diri seseorang untuk berupaya mencapai target yang telah ditetapkan, bekerja keras untuk untuk mencapai keberhasilan dan memiliki keinginan untuk mengerjakan sesuatu secara lebih baik dari sebelumnya.

Motivasi Berprestasi menurut Chaplin adalah pertama kecenderungan memperjuangkan kesuksesan atau memperoleh hasil yang di dambakan, kedua Keterlibatan ego dalam suatu tugas, ketiga Pengharapan untuk sukses dalam melaksanakan suatu tugas yang diungkapkan oleh reaksi-reaksi. Pupuh Fathurrohman dan AA Suryana menyatakan bahwa motivasi brprestasi merupakan suatu dorongan dalam diri seseorang untuk melakukan atau mengerjakan suatu kegiatan dngan sebaik-baiknya agar mencapai prestasi dengan peringkat terpuji, Motivasi berprestasi seorang guru diperlukan untuk meningkatkan semangat kerja dan untuk mencapai kemajuan karir. 
Pentingnya motivasi berprestasi untuk guru adalah cenderung untuk meningkatkan atau mempertahankan kecakapan dalam semua bidang, dengan standar kualitas yang tinggi untuk mencapai tujuan. Kemudian motivasi berprestasi menjadi suatu kecenderungan untuk melakukan sesuatu sebaik dan secepat mungkin, meliputi bekerja keras, harapan untuk sukses kekhawatiran untuk gagal, dan keinginan untuk memperoleh hasil kerja yang maksimal. Indikator yang digunakan adalah semangat kerja, wewenang dan tanggung jawab, tingkat kesulitan dan kemudahan pekerjaan, promosi, partisipasi dalam pemecahan masalah, bekerja bersama-sama, komunikasi dengan pimpinan, dorongan untuk lebih giat bekerja kepada teman yang lain, menunjukkan keteladanan pada rekan kerja, serta membantu teman dalam bekerja.

Hal-hal yang mempengaruhi motivasi berprestasi guru salah satunya adalah kondisi fisik lingkungan kerja. Lingkungan kerja memiliki pengaruh yang mendasar terhadap kinerja guru. Lingkungan kerja adalah kondisi fisik dan sosiologis. Lingkungan kerja yang baik sangat mempengaruhi kondisi kerja. Kondisi kerja yang aman, nyaman dan menyenangkan akan mampu menciptakan kinerja guru yang lebih baik. Setiap orang memiliki wawasan yang berbeda tentang lingkungan kerja, namun secara umum syaratsyarat terciptanya lingkungan kerja yang diinginkan, antara lain menyangkut pemenuhan kebutuhan hidup, keamanan, perlengkapan, alat peraga, ruang guru dan sebagainya. Faktor lain yang juga menciptakan lingkungan kerja adalah sikap pemimpin yang adil dan bijaksana. Guru menghendaki untuk diperlakukan secara adil dan bijaksana dalam tugas dan tanggung jawab yang dibebankan kepadanya.

Lingkungan kerja merupakan hal yang penting untuk karyawan dimana mereka setiap hari melakukan kegiatan. Bahwasanya lingkungan kerja berpengaruh terhadap hasil kerja karyawan. Karyawan akan mampu melaksanakan kegiatannya dengan baik, sehingga dicapai suatu hasil yang optimal, apabila diantaranya ditunjang oleh suatu kondisi ligkungan kerja yang baik. Sebaliknya bisa dikatakan, suatu kondisi lingkungan dikatakan baik apabila dalam kondisi yang demikian karyawan bisa melaksanakan kegiatannya dengan optimal, dengan sehat, aman, dan selamat. Ketidaknyamanan lingkungan kerja dapat terlihat akibatnya dalam waktu yang lama. Lebih jauh lagi, keadilan lingkungan yang kurang baik dapat menuntut tenaga dan waktu yang lebih banyak yang tentunya tidak mendukung diperolehnya rancangan sistem kerja yang efisien dan produktif. 
Kesejahteraan pekerja merupakan salah satu tujuan yang hendak dicapai dalam dunia usaha baik itu pengusaha, karyawan, maupun instansi pemerintahan yang dalam tugas pokoknya mengelola sumber daya manusia. Hal ini menuntut perlunya kenyamanan dan keamanan pekerjaan dlam bekerja karena pekerja atau keryawan sebagai titik sentral dalam perusahaan. Penyebab kecelakaan kerja yang terbesar adalah factor manusia, yaitu kurangnya kesadaran baik dari pihak perusahaan maupun dari karyawan itu sendiri terutama dalam menjalankan tugasnya. Masih banyak anggapan bahwa pelaksanaan pengendali kecelakaan dan perhatian terhadap kondisi lingkungan kerja kurang bermanfaat, dan akan mnambah biaya. Sikap inilah yang secara tidak langsung dapat menurunkan kepuasan dalam bekerja bahkan produktivitas. Selanjutnya, seharunya lingkungan tempat kerja harus diusahakan memenuhi syarat-syarat kebersihan dalam bekerja.

\section{METODE}

Penelitian kuantitatif adalah pengukuran data kuantitatif dan statistik objektif melalui perhitungan ilmiah berasal dari sampel orang-orang atau penduduk yang diminta menjawab atas sejumlah pertanyaan tentang survey untuk menentukan frekuensi dan persentase tanggapan mereka.

Penelitian ini dilaksanakan di SMK Abdi Negara Binjai yang beralamat Jl. T Amir Hamzah No. 682, Kec. Binjai Utara, Kota Binjai, Propinsi Sumatera Utara. Penelitian ini dilaksanakan pada bulan Juni s/d bulan September 2018.

Populasi dalam penelitian ini adalah seluruh Guru SMK Abdi Negara Binjai dengan Jumlah Guru 31 orang. Arikunto mengatakan : ’Untuk sekedar ancer-ancer maka apabila subjeknya kurang dari seratus baik di ambil semua sehingga penelitiannya merupakan penelitian populasi. Selanjutnya jika subjek besar dapat diambil antara 10-15\% atau 20$25 \%$ ". Berdasarkan pendapat diatas penulis mengambil sampel sebanyak 31 orang $100 \%$ dari jumlah popolasi. Pengambilan sampel dilakukan secara acak (random sampling). Dengan teknik ini setiap anggota diberi peluang yang sama untuk menjadi anggota sampel. Dikarenakan jumlah populasi dapat diketahui jumlahnya sebanyak 31 orang, oleh karena itu peneliti dapat menentukan sampel sebanyak jumlah populasi yaitu 31 orang guru.

Instrumen yang digunakan untuk mengumpulkan data primer dalam penelitian ini adalah kuesioner. Peneliti menggunakan kuesioner yang dikembangkan oleh Delgado dan 
Munuera. Skala yang digunkan dalam penelitian ini adalah Skala Likert 4 poin, dari "Sangat tidak setuju”sampai "Sangat setuju”. Pengujian Instrumen penelitian menggunakan Uji Reliabilitas, Uji Vaiditas. Teknik analisis data yang digunakan dalam penelitian ini adalah Uji Normalitas, Uji Linearitas, dan Uji Hipotesis.

\section{HASIL DAN PEMBAHASAN}

\section{Uji Standart Normalitas}

Uji normalitas dilakukan untuk mengetahui apakah distribusi data penelitian setiap variabel telah menyebar secara normal. Uji normalitas dilakukan dengan metode satistik menggunakan program SPSS Version 20.0 Berdasarkan hasil data dapat dilihat bahwa nilai linearitas sebesar 1,000 atau $\mathrm{P}>0,05$ yang artinya kedua variabel berhubungan secara signifikan.

Uji Linearitas bertujuan untuk mengetahui apakah dua variabel mempunyai hubungan yang linear atau tidak secara signifikan. Berikut adalah hasil uji linearitas. Berdasarkan tabel diatas dapat dilihat bahwa nilai linearitas sebesar 1,000 atau P>0,05 yang artinya kedua variabel berhubungan secara signifikan.

Hasil penelitian dilakukan untuk menguji hipotesis penelitian yang mana hipotesis penelitian yang mana hipotesis penelitan adalah :

Ho : Tidak ada hubungan yang tinggi atau rendah persepsi Guru tentang kondisi fisik lingkungan kerja dengan motivasi prestasi guru SMK Abdi Negara Binjai.

Ha : Ada hubungan yang tinggi atau rendah persepsi guru tentang kondisi fisik lingkungan kerja dengan motivasi prestasi guru SMK Abdi Negara Binjai.

Berikut adalah hasil penelitian hubungan antara persepsi guru tentang kondisi fisik lingkungan kerja dengan motivasi prestasi guru SMK Abdi Negara Binjai, hasil penelitian dilakukan menggunakan SPSS Version 20.0. Dari hasil hipotesis dapat diketahui bahwa nilai korelasinya adalah 0,000 yang $\mathrm{P}<0,05$ maka yang artinya Ho diterima bahwa terdapat hubungan antara persepsi guru tentang kondisi fisik lingkungan kerja dengan motivasi prestasi guru SMK Abdi Negara Binjai.

\section{SIMPULAN}

Kesimpulan kajian teori dan hasil analisis serta mengacu pada perumusan masalah yang telah diuraikan bahwa hasil dari uji tersebut adalah Nilai variabel motivasi prestasi 
terdistribusi secara normal dengan nilai $\mathrm{p}>0,05(0,967>0,05)$. Dan nilai variabel lingkungan kerja terlihat secara normal dengan nilai $\mathrm{p}>0,05(0,978>0,05)$. Nilai linearitas sebesar 1,000 atau $\mathrm{p}>0,05$ yang artinya kedua variabel berhubungan secara signifikan. Hasil reliabilitas menggunakan formula koefisien Crobach'Alpha di nyatakan tinggi jika mendekati angka 1, skala lingkungan kerja 0,940 dan skala motivasi prestasi 0,931 dan dua skala tersebut dapat dilihat bahwa reliabilitas skala sangat kuat karena nilai reliabilitas mendekati angka 1. Analisis ini dengan mengkorelasikan masing-masing skor item dengan skor total. Dan hasil validasi skala lingkungan kerja dari 40 skala yang di uji terdapat 6 item yang tidak valid artinya $\mathrm{p}<0,025$, sedangkan skala motivasi prestasi dari 40 item yang di uji terdapat 5 item yang tidak valid. Berdasarkan hasil analisis data diperoleh nilai korelasinya atau $\mathrm{p}=0,000$ yaitu lebih kecil dari taraf signifikansi $\mathrm{p}<0,05$ yang artinya kedua variable berhubungan secara signifikan, dapat ditarik kesimpulan sebagai berikut: terdapat hubungan antara persepsi guru tentang kondisi fisik lngkungan kerja dengan motivasi prestasi guru SMK Abdi Negara Binjai.

\section{REFERENSI}

Afani, M.Zainul. 2008, Hubungan Persepsi Lingkungan Kerja Dengan Kepuasan kerja Karyawan Diperusahaan Daerah air Minum (PDAM), Kota Madiun. Dekan Fakultas Psikologi UIN Malang.

Badawi, Achmad. 2014, Pengaruh Lingkungan Kerja, dan Motivasi Kerja terhadap Kepuasan Kerja Serta Implikasinya Pada Kinerja Guru. Universitas Muhammaddiyah Tangerang, Vol 2, No 1, Hlm: 23

Sarwono, (1993). Teori-teori Psikologi Sosial, Jakarta: PT Raja Grafindo.

Sedarmayanti. (2001). Sumber Daya Manusia dan Produktivita Kerja. Bandung: Mandar Maju.

Sugiyono dan Rekan. 2011, Pengaruh Pendidikan, Motivasi Kerja, dan Lingkungan Kerja Terhadap Kinerja Guru. Fakultas Ekonomi Universitas Slamet Riyadi Surakarta, Vol 5, No 1. Hal: 4. 